Apidologie, 1985, 16 (2), 157-164

\title{
THE ORIGIN OF THE PORE IN THE DRONE CELL CAPPING OF APIS CERANA FABR.
}

\author{
H. HANEL and F. RUTTNER \\ Institut für Bienenkunde (Polytechnische Gesellschaft) \\ der Universität Frankfurt, D-6370 Oberitrsel
}

\section{SUMMARY}

The pore in the cappings of the drone cells of Apis cerana is the result of the local dissolution of the cocoon from inside (presumably by the action of a drone larva secretion) and by scraping off the outer wax layer by worker bees. The biological significance of this unique behaviour is not known.

\section{INTRODUCTION}

During a journey to Sumatra in 1912, the entomologist H.v. ButTEL-REePleN (1918) made two strange observations simultaneously in a colony of Apis cerana (A.c.) : The drone cells showed a small central hole in the cappings (Fig. 1), not found in the three other Apis species; and when the cappings were removed, he detected rather large, crab-like mites in the cells (described by OUdEMANS 1904 as Varroa jacobsoni). The pore in the capped drone cells of $A$. cerana had first been observed by E. JACOBson, as mentioned in a letter to ButTel-ReEPEN (1907).

It is not surprising that a causal connection between the two observations was discussed by entomologists of this time, e.g. by Buttel-REEPEN, 1907, 1918 : « This apparent ventilation hole brought us to the assumption that it does not come from the bee at all, but that it was made by different organisms $\gg$.

Immediately after capping the cover of the A.c. drone cell looks quite the same as the cell cover in other Apis species : a smooth wax cover on top and a homogenouos cocoon beneath (Fig. 1, right). However, one day after capping the worker starts to scrape off the wax cover. Now in the central area a cone with a pore appears. Gradually, in most cases within three day, all the wax is 
removed, revealing a yellowish, hardened surface of the cocoon (Sakagami, 1960). TOKUDA (1922) describes the pore as « a funnel, measuring $0.4 \mathrm{~mm}$ in depth and $0.25 \times 0.5 \mathrm{~mm}$ in diameter, the outside opening being wider than the inside, and fringed on the inside edge with a heavy mass of a brown substance ».

These dimensions tend to indicate that no relation can exist between the incidental presence of the much larger Varroa and the pore.

Thus the question concerning the origin as well as the significance of the pore remained unanswered.

\section{MATERIAL AND METHODS}

Dione combs from Pakistan, China and Malaysia were investigated. Dionc cells in different stages were dissected and photos were made with a macro lens (up to $1: 10$ ) and a scanning electron microscope $(1: 50-1: 100)$.

\section{RESULTS}

Freshly capped drone cells show the normal Apis cell cover, with a complete wax layer as outer and a uniform, purely white cocoon as inner layer (Fig. 2 a).

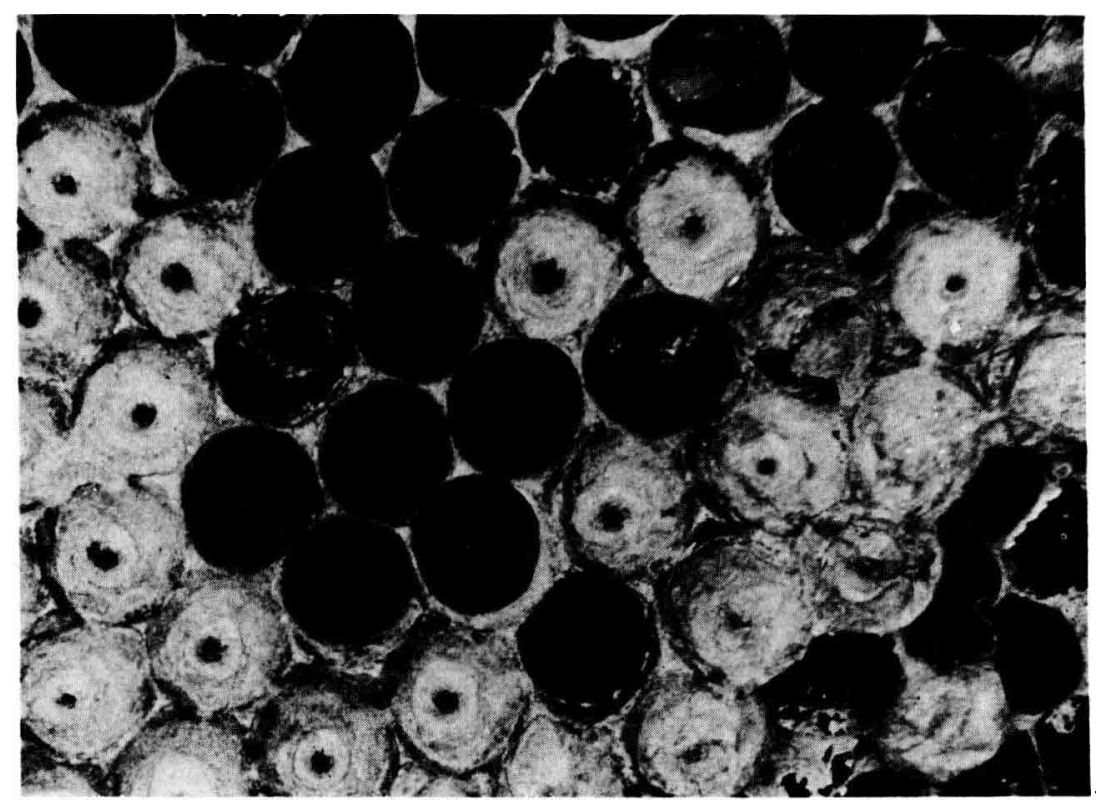

FIG. 1. - Comb of Apis cerana with capped drone cells

The cells to the right without a pore are freshly capped. (Photo BiedermanN). 

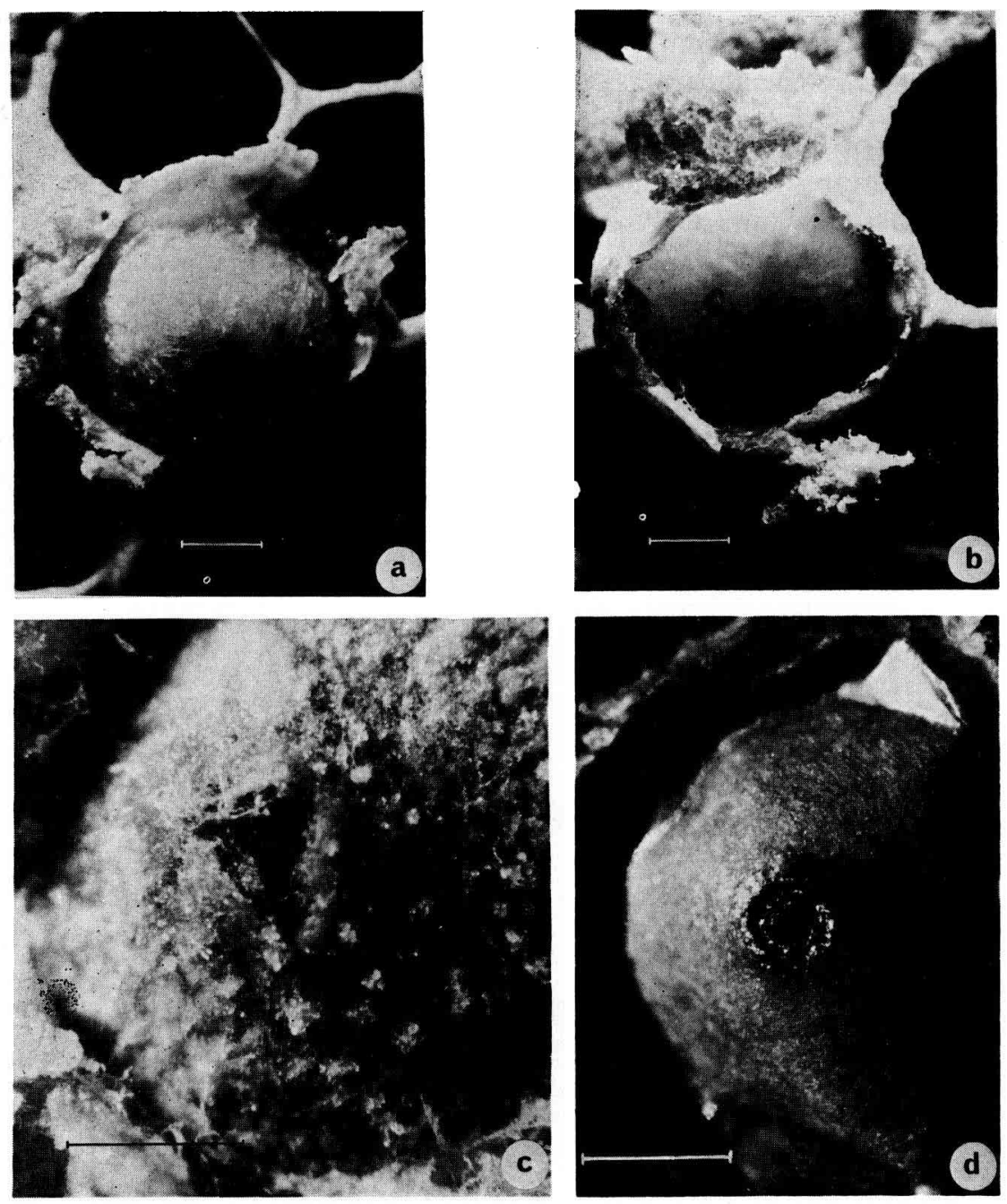

FIG. 2. - Development of the pore in the capping

a : Freshly capped cell.

b : One day later : beginning dehiscence of the tissue visible as slightly darker cross bencath the surface.

$c$ : The burst cupola of the capped drone cell with single fibres stretching across the opening. a-c : Wax cover artificially removed.

d : Final stage of the pore.

Horizontal line : $0.2 \mathrm{~mm}$. 
However, one day later the cocoon takes on a yellowish colour. In the central area darker, radially arranged stripes appear in the deeper layers of the cocoon (Fig. 2 b). This is the beginning of the fission of the cocoon. At this time the outer surface of the cocoon and the wax cover are still intact.

Then the cocoon bursts. Single thin fibres persist and stretch across the fissure (Fig. 2 c). A shiny yellowish-brown substance surrounds a round hole, arching outwards to form the cone (Fig. $2 \mathrm{~d}$ ). At this stage the outer wax layer is removed by worker bees and the thickly waxed, holed cap appears.

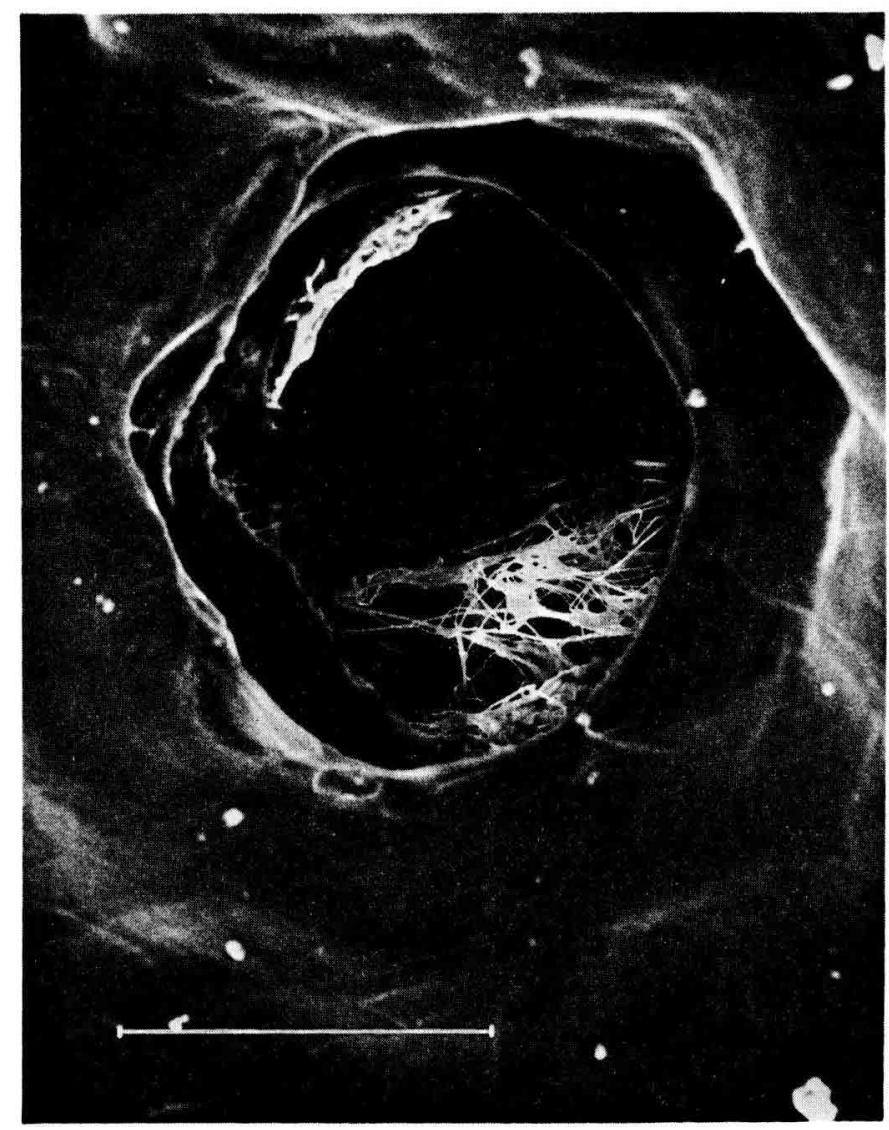

Fic. 3. - Channel of the pore at an early stage

Partly free fibres and remaining threads imbedded into a homogenous substance.

It can be demonstrated by means of a scanning microscope that the localized destruction of the cocoon is caused by a process of dissolution. The fibrous tissue 
of the cell cupola is transformed to a more or less homogenous, transparent and yellowish substance, which includes single remaining threads (Fig. 3). The free cocoon web is visible in certain spots only, but even there many of the fibres are glued together (Fig. 4). Inside the channel only irregularly coagulated structures are visible (Fig. 5). Evidently the yellowish substance impregnating the cocoon hardens as soon as it is exposed to the air.

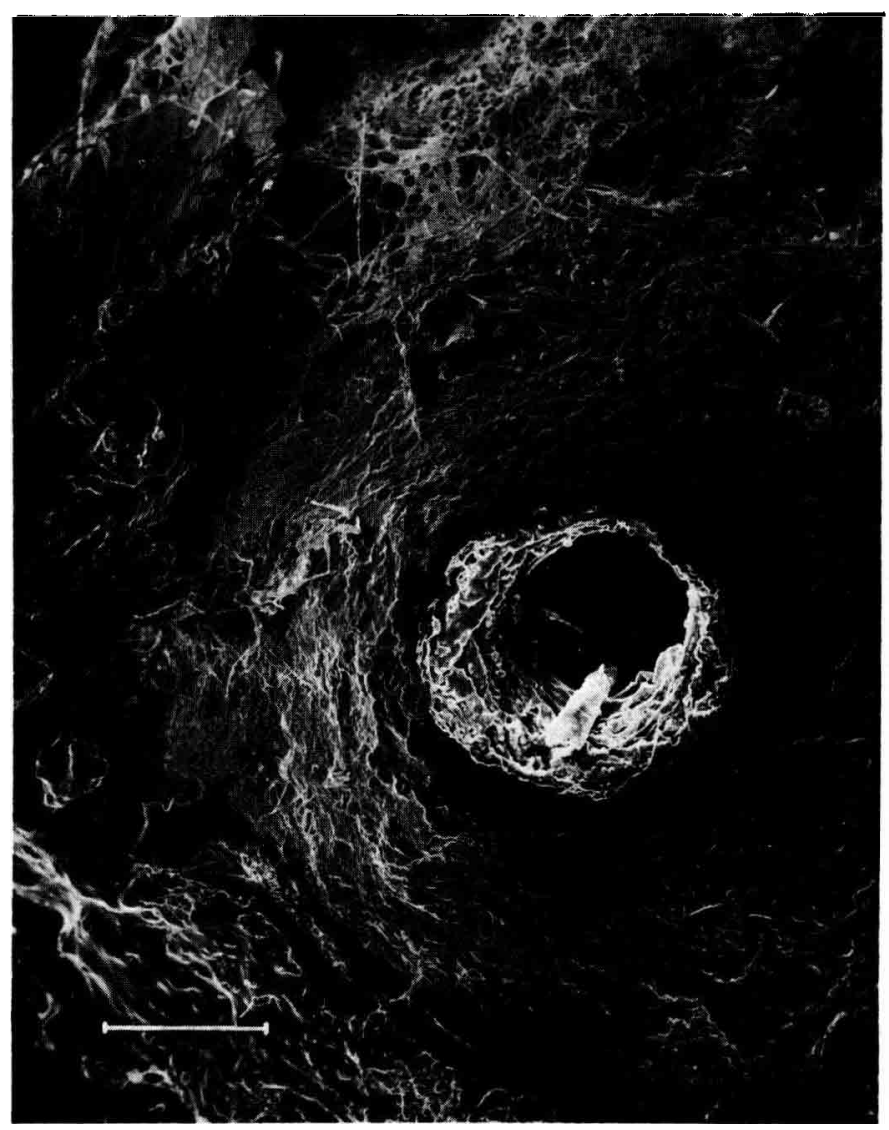

Fig. 4. - Cell capping from inside

The values measured for the diameter of the pore correspond approximately to those given by TokUdA (1922) : mean of seven measurements $262,8 \mathrm{fm}$ $(\mathrm{s}=47.9$; range $182-328$; $\mathrm{m})$. 


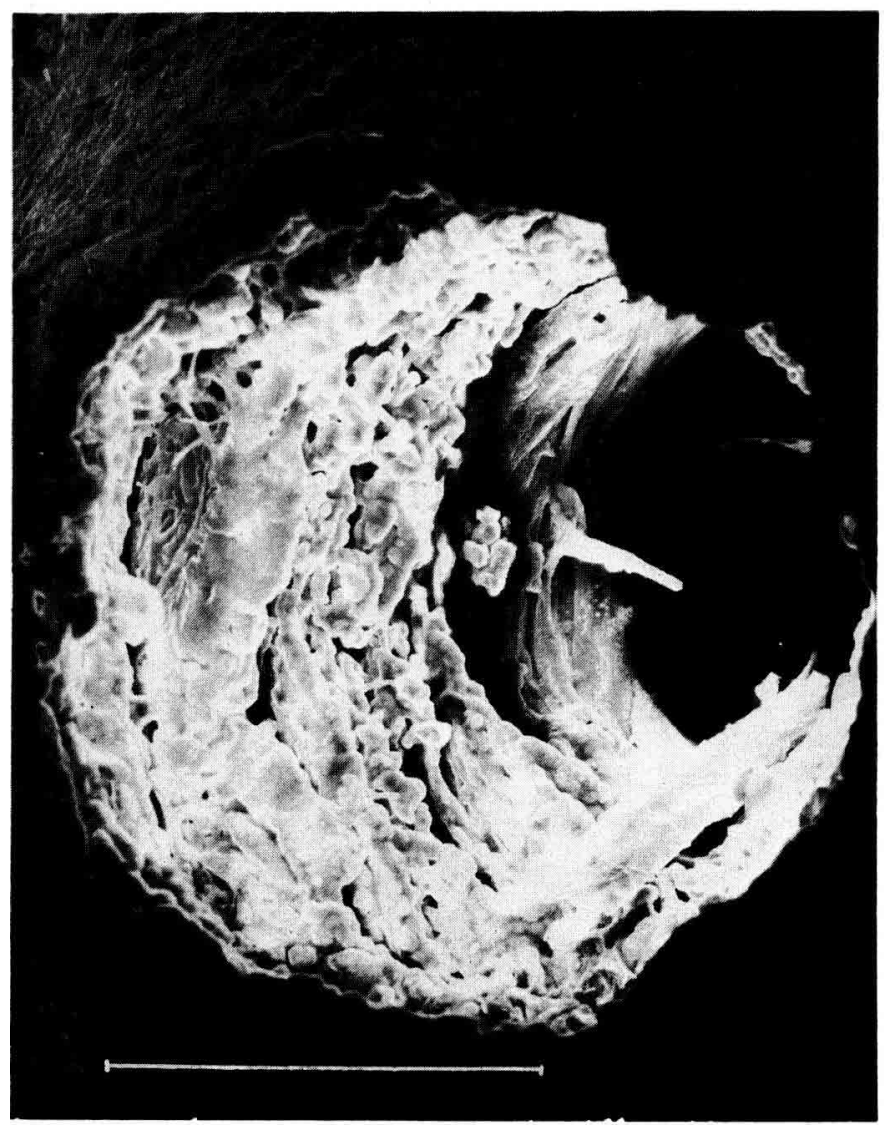

Fig. 5. - Channel of the pore, final stage

\section{DISCUSSION}

The yellow spot in the central part of the cocoon corresponds to the position of the mouth parts of the drone larva. Thus it can be assumed (though it is not yet proven by experiment) that the dissolution of the cocoon is due to the action of a secretion of the larva. Cocoon-dissolving enzymes were reported from other insects. In Lepidoptera (Bombyx mori and others) the enzyme cocoonase is found (up to $0.1 \mathrm{mg}$ per individual) which dissolves the fibres and creates the passage for the butterfly to hatch (KAFATOS, 1972). Whether the formation of the cone round the pore has something to do with the activities of the larva or whether it is the result of a mere mechanical process (tensions during the dissolution of the cocoon) has not been investigated. 
The second question, regarding the biological significance of this strange phenomenon, however, remains unanswered. The argument, that the pore serves for better ventilation of the pupa, because $A$. cerana occurs mainly in hot climates, may not hold true since $A$. mellifera occurs in countries with even higher temperature. These two «sister species » are similar in most respects (also in ecological requirements) and this pore, unique in the genus $A p i s$, is one of the main discriminant characters. This consideration makes this enigma still harder to understand. At present we will not even attempt an hypothesis about the adaptative value of the pore in the drone cocoon of Apis cerana.

Received for publication in December 1984.

Accepted for publication in January 1985.

\title{
ACKNOWLEDGEMENTS
}

We wish to thank Dr. Rafiq Ahmad, Pakistan Agric. Res. Council Islamabad and Dr. G.D. Waller, Bee Res. Center, USDA, Tucson, for providing sealed ceranta drone comb.

\author{
RÉSUMÉ \\ ORIGINE DU PORE DANS LOPERCULE DE LA CELlULE DE MALE \\ CHEZ APIS CERANA FABR.
}

Les pores dans les opercules des cellules d'Apis cerana ont été observés pour la première fois par E. JACobson. Buttel-ReEpen a mis ce «trou de ventilation» en rapport avec la présence simultanée de Varroa jacobsoni; pourtant cette supposition n'est pas valable en raison du diamètre réduit de l'ouverture - outre que Varroa jacobsoni n'est absolument pas présent dans toute l'aire de cerana.

Au début les cellules de mâles aussi sont recouvertes d'une couche de cire continue; mais elle est démolie par les abeilles dès le premier jour après loperculation, si bien que le cocon de la nymphe est visible par le pore percé à travers le cône central.

Les auteurs ont étudié en macrophotog:aphie et au microscope électronique à balayage des cellules de mâle d'Apis cerana du Pakistan, de Chine et de Malaisie, dans le but de déterminer les stades de formation du pore. Peu après loperculation, une tâche jaune est visible sur la partie bombée du cocon, qui jusqu'à présent était bien blanc et intact. Dans cette région les fibres du cocon se dissolvent peu à peu et des fissures radiaires apparaissent (Fig. 2 a, b, c). La substance liquéfiée dessine un anneau autour de l'ouverture qui se forme et imprègne la trame du cocon alentour. (Fig. $2 \mathrm{~d}$ et 3-5). La tâche jaune et le pore se forment à l'endroit du cocon situé juste au-dessus de la tête de la larve. C'est pourquoi nous pensons que la dissolution locale du cocon est causée par une sécrétion des prénymphes mâles.

On n'a aucune idée de la signification biologique de ce phénomène particulier. 


\section{ZUSAMMENFASSUNG}

\section{DIE ENTSTEHUNG DER PORE IM ZELLDECKEL DER DROHNENZELLEN VON APIS CERANA FABR.}

Die eigenartigen Poren in den Zelldeckeln von $A$. cerana wurden von E. JACOBSON erstmals beobachtet. BUTTEL-REEPEN brachte dieses «Ventilationsloch» mit der gleichzeitigen Anwesenheit der Milbe Varroa jacobsoni in Verbindung, doch ist diese Vermutung wegen des geringen Durchmessers der Öfnung nicht haltbar - ganz abgesehen davon, daß Varroa $j$. auch im cerana-Gebiet keineswegs überall vorkommt.

Anfangs sind auch die Drohnenzellen mit einer geschlossenen Wachsschicht bedeckt, die aber schon nach dem ersten Tag nach der Verdeckelung von den Bienen wieder abgetragen wird, so daß der Puppenkokon mit der auf einem Konus liegenden Pore sichtbar wird.

Die Autoren haben Drohnenzellen von A. cerana aus Pakistan, China und Malaysia mit dem Ziel untersucht, die Stadien der Entstehung der Zellpore in Makro- und REM-Aufnahmen festzuhalten. Schon kurz nach Verdeckelung ist an der Wölbung des bisher geschlossenen, rein weissen Kokons ein gelber Fleck zu sehen, in dessen Bereich sich allmählich die Kokonfasern auflösen, wobei zunäichst radiäre Spalten entstehen (Abb. 2 a, b, c). Die verflüssigte Substanz bildet einen Ring um die sich bildende Öffnung und imprägniert das Kokongespinst der Umgebung (Abb. 2 d und 3-5). Der gelbe Fleck und die Pore entstehen an der Stelle des Kokons, die unmittelbar über dem Kopf der Larve liegt. Es ist deshalb anzunehmen, dal die lokale Auflösung des Kokons durch ein Sekret der Drohnenstreckmade bewirkt wird.

Über die biologische Bedeutung dieser eigenartigen Erscheinung gibt es nicht einmal Vermutuingen.

\section{BIBLIOGRA PHY}

Buttel-Reepen H.v., 1907. - Psychobiologische und biologische Bcobachtungen an Ameisen, Bienen und Wespen. Naturwiss, Wochenschr. Neue Folge 6/30, 465-487.

Buttei-Reepen H.v., 1918. - Seltsame Mitbewohner der Bienenzellen. Bienenwirtsch. Centralbl. 54, 78-80.

JACOBSON E., 1905, - See ButTel-REEPEN, 1907.

Kafatos F.C., 1972. - Cited by M. Agosin in : M. Rockstein ed. Biochemistry of insects, Academic Press, London, New Yoik, 1978, 93-144.

Sakagami Sh.F., 1960. - Preliminary report on the specific difference of behaviour and other ecological characters between European and Japanese honeybees. Acta Hymenopterologica. 1, 171-198.

TokUdA Y., 1922. - A pore of the japonica drone cocoon. Bee World, 3, 89.

Tokuda Y., 1924. - Studies on the honeybee, with special reference to the Japanese honeybee. Tr. Sapporo Nat. Hist. Soc. 9, 1. 